\title{
Effectiveness of Botanical Insecticide Mixture of Neem Seed Extract and Citronella Oil Against Cotton Bollworm (Helicoverpa armigera Hubner) and Armyworm (Spodoptera litura Fabricius)
}

\author{
Sujak $^{1 *}$, Subiyakto ${ }^{1}$, Dwi Adi Sunarto ${ }^{1}$ \\ ${ }^{1}$ Indonesian Sweetener and Fiber Crops Research Institute, PO Box 199 Malang, Indonesia \\ *Corresponding author.Email: sujakbalittas@gmail.com
}

\begin{abstract}
Irrational use of synthetic insecticides can cause pollution of water, soil, air, and agricultural products; it affects the health of consumers and agricultural workers, as well as pest resistance and resurgence, killing beneficial animals, and pest outbreaks. Therefore it is necessary to find alternative solutions that are effective, efficient, and environmentally friendly. One of them is a plant-based insecticide from neem seed extract and citronella oil. This study aimed to determine the effectiveness of a mixture of botanical extracts of neem seed extracts (NSE) (75\%) and citronella oil (CO) (25\%) against Helicoverpa armigera and Spodoptera litura. The treatment consisted of a mixture of NSE and CO at various concentrations (1) $1.25 \mathrm{~mL} / \mathrm{L}$ of water, (2) 2.5 $\mathrm{mL} / \mathrm{L}$ of water, (3) $3.5 \mathrm{~mL} / \mathrm{L}$ of water, (4) $5 \mathrm{~mL} / \mathrm{L}$ of water, (5) pure NSE with NSE concentration of $5 \mathrm{~mL} / \mathrm{L}$ of water and (6) control. The study used randomized block design repeated four times, each repetition consisting of 25 second and third instars larvae. The results showed that the mixture treatment of neem seed extract and citronella oil at a concentration of $1.25 \mathrm{~mL} / \mathrm{L}$ effectively caused mortality on both pests and was not significantly different when compared with higher concentrations and pure NSE.
\end{abstract}

Keywords: plant-based insecticide, pollution, synthetic insecticides

\section{INTRODUCTION}

Helicoverpa armigera Hubner and Spodoptera litura Fabricius are polyphagous pests. Both attack various commodities of major crops, including soybean, corn, tobacco, and vegetables. As yet, pest control is still dependent on synthetic insecticides. Irrational use of synthetic insecticides leaves insecticide residues in agricultural products and environmental pollution along with increasing production costs. The high expense of pest control started since the monetary crisis in 1997/98, where insecticides price rose 2-3 higher, which led to many traditional farmers cannot afford them. These have led to development of alternative insecticides that are relatively inexpensive, effective in killing pests, and environmentally friendly [1]. A promising alternative is to explore plants with insecticidal properties to be developed as botanical insecticides. Botanical insecticides have a great possibility to develop because Indonesia has a high diversity of plants, and that might contain active insecticide compounds.

Botanical insecticides (botanicals) are chemicals with insecticidal properties extracted from plants. Botanicals allegedly cause little threat to the environment and almost none to plants, affect only targets insects, delaying insect resistance rate to chemical compounds, compatible with other pest control strategies, and produce healthy agricultural products free from synthetic insecticide residues due to the compounds that easily breakdown in nature [2]. The application of plant-based insecticides NSE is useful in controlling caterpillars and is compatible with biological control techniques and biopesticides [2-5]. The disadvantages of botanical insecticides, in general, it does not kill the pests instantly (slow effects), it is degraded easily under sunlight, and sometimes require repeated spraying because of its short residual period [6-8]. Also, according to some farmers, the botanicals like neem seed extract has low effectiveness, and it has an inconvenience pungent odor.

These limitations can be overcome by increasing the formulation through the addition of other ingredients to remove odors and increase effectiveness. Citronella extract (Cymbopogon nardus L. Rendle) can act as a bioinsecticide, and it contains citronella and geraniol that have a characteristic odor that, in general, it is not favored by insects. The addition to NSE solution is expected to increase the effectiveness and eliminate the pungent odor caused by the neem seed extract solution [2]. Thus, this study aimed to improve the effectiveness of neem seed extracts and eliminate pungent odors by adding citronella oil with specific concentrations. 


\subsection{Materials and Methods}

The study was conducted at the Entomology Laboratory and the Screening House of Indonesian Sweetener and Fiber Crops Research Institute Malang, from January to December 2012. Based on previous study by Subiyakto et al. [9], $75 \%$ neem seed extract and $25 \%$ citronella oil were mixtureed with six concentrations as follows: $1.25,2.5,3.5$, and $5 \mathrm{~mL} / \mathrm{L}$ of water, pure NSE with NSE concentration of $5 \mathrm{~mL} / \mathrm{L}$ of water as well as water as control. Randomized block design with four replications was used in this study. Second and third instars larvae of $S$. litura and $H$. armigera were reared on the laboratory conditions. Along with five tobacco plants individually planted in separate pots that were used for each treatment. These larvae were placed in a petri dish (25 larvae per treatment) and treated with insecticides by sprayed directly to the larvae. Larvae were transferred to tobacco plants that already sprayed with the same concentration. Mortality was assessed at 24, 72, 96, and $120 \mathrm{hr}$ after of insecticides application. The mortality was analyzed statistically and determine the significant differences from each treatment using Duncan's Multiple Range Test DMRT) test with a 5\% confidence level.

\subsection{Our Contribution}

This paper presents the effectiveness of a botanical insecticide mixture of neem seed extract and lemongrass oil on pests of cotton worms and armyworms. The use of botanical insecticide produced in the form of a mixture of neem seed extract and lemongrass oil turned out to be effective in killing cotton worms and armyworms. Thus the discovery of this type of botanical insecticide can provide options for farmers to use environmentally friendly insecticides.

\subsection{Paper Structure}

This paper organized as follows. The first part is an introduction that introduces the need for this research activity to be carried out. The second part is in the form of a background which discusses the results of research on the effectiveness of botanical insecticides, a mixture of neem seed extracts and lemongrass oil against cotton worms and armyworms. Finally, the last part is the conclusion.

\section{RESULTS AND DISCUSSION}

After one day of the insecticide exposure, the percentage mortality of $H$. armigera larvae not significantly different on a few treatments (Table 1). As in the treatment with NSE $75 \%+\mathrm{CO} 25 \%$ ratio, $42.32 \%$ mortality was observed in NSE concentration $3.5 \mathrm{~mL} / \mathrm{L}$, whereas the lowest was in NSE concentration $5 \mathrm{~mL} / \mathrm{L}$, which caused mortality $22.68 \%$. The larval mortality on NSE $100 \%$ is not significantly different from the NSE and CO mixture (NSE $3.5 \mathrm{~mL} / \mathrm{L}$ ).

Mortality of $H$. armigera tended statistically similar between all of SNE and CO treatments on 72, 96, and 120 $\mathrm{hr}$ after application. After five days of exposure, there were no significant differences in larval mortality recorded between the combination of NSE and $\mathrm{CO}$ at a concentration of $1.25 \mathrm{~mL} / \mathrm{L}$ and $5 \mathrm{~mL} / \mathrm{L}$ with NSE $100 \%$. Hence, the effectiveness of NSE and CO with a concentration of $1.25 \mathrm{~mL} / \mathrm{L}$ is equally effective as other concentrations.

Table 2 shows that all tested combinations and concentrations caused more than $50 \%$ mortality of $H$. armigera on all application tests, which repeated three times. The results indicated that even the lowest concentration of NSE $(1.25 \mathrm{~mL} / \mathrm{L})$ had a similar mortality rate with higher concentrations. Thus, this experiment demonstrated that the efficiency of the lowest tested concentration not significantly different compared to other

Table 1 The mortality rate of different concentrations botanicals against second and third instar H. armigera under laboratory conditions

\begin{tabular}{|c|c|c|c|c|c|c|}
\hline \multirow{2}{*}{ Treatments } & \multirow{2}{*}{$\begin{array}{c}\text { NSE } \\
\text { concentrations } \\
(\mathrm{mL} / \mathrm{L})\end{array}$} & \multirow{2}{*}{$\begin{array}{l}\text { No. of } \\
\text { exposed } \\
\text { larvae }\end{array}$} & \multicolumn{4}{|c|}{$\begin{array}{c}\text { Mean percentage mortality of } 2^{\text {nd }} \text { and } 3^{\text {rd }} \text { instar } \\
\text { after }\end{array}$} \\
\hline & & & $24 \mathrm{hr}$ & $72 \mathrm{hr}$ & $96 \mathrm{hr}$ & $120 \mathrm{hr}$ \\
\hline NSE $75 \%+\mathrm{CO} 25 \%$ & 1.25 & 25 & $26.68 \mathrm{ab}$ & $69.32 \mathrm{~b}$ & $74.68 \mathrm{~b}$ & $84.00 \mathrm{~b}$ \\
\hline NSE $75 \%+\mathrm{CO} 25 \%$ & 2.5 & 25 & $30.68 \mathrm{ab}$ & $76.00 \mathrm{~b}$ & $78.68 \mathrm{~b}$ & $82.68 \mathrm{~b}$ \\
\hline NSE $75 \%+\mathrm{CO} 25 \%$ & 3.5 & 25 & $42.32 b$ & $76.00 \mathrm{~b}$ & $81.32 \mathrm{~b}$ & $86.68 \mathrm{~b}$ \\
\hline NSE $75 \%+\mathrm{CO} 25 \%$ & 5 & 25 & $22.68 \mathrm{ab}$ & $82.68 \mathrm{~b}$ & $88.00 \mathrm{~b}$ & $90.68 \mathrm{~b}$ \\
\hline NSE $100 \%$ & 5 & 25 & $42.68 b$ & $69.32 \mathrm{~b}$ & $77.32 \mathrm{~b}$ & $86.68 \mathrm{~b}$ \\
\hline Control & - & 25 & $2.67 \mathrm{a}$ & $18.68 \mathrm{a}$ & $20.00 \mathrm{a}$ & $21.32 \mathrm{a}$ \\
\hline
\end{tabular}

Percentage mortality followed by different letters in the same column are significantly different at 5\% DMRT confidence level 
Table 2 Effect of combination of neem seed extract and citronella oil with different concentrations against $H$. armigera under laboratory conditions.

\begin{tabular}{|c|c|c|c|c|}
\hline \multirow{2}{*}{ Treatments } & NSE concentrations & \multicolumn{3}{|c|}{ Application (\% mortality) } \\
\cline { 2 - 5 }$(\mathbf{m L} / \mathbf{L})$ & 1.25 & $69.3 \mathrm{~b}$ & $65.6 \mathrm{~b}$ & $84.6 \mathrm{~b}$ \\
\hline NSE 75\% + CO 25\% & 2.50 & $72.6 \mathrm{~b}$ & $65.6 \mathrm{~b}$ & $83.3 \mathrm{~b}$ \\
\hline NSE 75\% + CO 25\% & 3.50 & $69.9 \mathrm{~b}$ & $69.3 \mathrm{~b}$ & $87.9 \mathrm{~b}$ \\
\hline NSE 75\% + CO 25\% & 5.00 & $81.3 \mathrm{~b}$ & $60.6 \mathrm{~b}$ & $91.3 \mathrm{~b}$ \\
\hline NSE 75\% + CO 25\% & 5.00 & $75.6 \mathrm{~b}$ & $68 \mathrm{~b} 3$ & $87.6 \mathrm{~b}$ \\
\hline NSE 100\% & - & $19.3 \mathrm{a}$ & $12.3 \mathrm{a}$ & $21.6 \mathrm{a}$ \\
\hline Control & & II & \\
\hline
\end{tabular}

Percentage mortality followed by different letters in the same column are significantly different at $5 \%$ DMRT confidence level

concentrations.

The treatments on day one after application did not show a significant effect on $S$. litura mortality rate (Table 3). The mixture of NSE and $\mathrm{CO}$ with $2.5 \mathrm{~mL} / \mathrm{L}$ concentration caused $64 \%$ of mortality 96 hrs after application (HAA), and it is increased steadily to $78.68 \%$ (9696 HAAHAA) and 84\% (120 HAA). The same trend showed on mixture treatment with NSE concentration level of $3.5 \mathrm{~mL} / \mathrm{L}$, which had a $38.68 \%$ mortality rate at 3 DAA and increased almost half of it on the 9696 HAAHAA $(72 \%)$ and became the highest mortality rate at 120 HAA $(89 \%)$. These results showed that $2.5 \mathrm{~mL} / \mathrm{L}$ of NSE concentration had an immediate effect on $S$. litura mortality rate than higher-level concentration.

In all treatments of botanical insecticide on 96 and 120 HAA showed a consistent effect on larvae mortality. Larval mortality ranged from 68-78.68 \% on 96 HAA and increased to $78.68-89 \%$ on 120 HAA. NSE $75 \%+\mathrm{CO}$ $25 \%$ treatment on $1.25 \%$ concentration level was actively causing $S$. litura armyworm mortality and did not significantly different when compared with higher concentration levels and NSE100\% treatment.

The treatment of mixture NSE $75 \%+\mathrm{CO} 25 \%$ with $1.25 \%$ concentration level had higher efficiency with $84 \%$ mortality for $H$. armigera and $80 \%$ for $S$. litura, which were not significantly different from treatment using higher concentration treatment $(5 \mathrm{~mL} / \mathrm{L})$ (Table 1 and 2$)$. Pesticide formulations can be said to be effective if they can kill $\geq 80 \%$ of test insects [1]. Based on these criteria, NSE $75 \%+\mathrm{CO} 25 \%$ can be classified as an effective botanical insecticide formula. The addition of clove oil or citronella oil into the neem seed extract formula containing azadirachtin active ingredient apparently can reduce NSE $100 \%$ of $5 \mathrm{~mL} / \mathrm{L}$ concentration level usage, and does not reduce its effectiveness level as a botanical insecticide. This result may be caused by citronella oil, which contains active insecticidal compounds such as citronellal, citronellol, and geraniol. The most abundant compound is

Table 3 The mortality rate of different concentrations botanicals against second and third instar $S$. litura under laboratory conditions

\begin{tabular}{|c|c|c|c|c|c|c|}
\hline & \multirow{2}{*}{ Treatments } & \multirow{2}{*}{$\begin{array}{c}\text { NSE } \\
\text { concentrations } \\
(\mathbf{m L} / \mathbf{L})\end{array}$} & $\begin{array}{c}\text { No. of } \\
\text { exposed } \\
\text { larvae }\end{array}$ & \multicolumn{4}{|c|}{ Mean percentage mortality of $\mathbf{2}^{\text {nd }}$ and $3^{\text {rd }}$ instar } \\
\cline { 5 - 7 } & & & $\mathbf{1}$ day & $\mathbf{3}$ days & $\mathbf{4}$ days & $\mathbf{5}$ days \\
\hline NSE 75\% + CO 25\% & 1.25 & 25 & $1.32 \mathrm{a}$ & $28.00 \mathrm{ab}$ & $68.00 \mathrm{~b}$ & $80.00 \mathrm{~b}$ \\
\hline NSE 75\% + CO 25\% & 2.50 & 25 & $13.32 \mathrm{a}$ & $64.00 \mathrm{c}$ & $78.68 \mathrm{~b}$ & $84.00 \mathrm{~b}$ \\
\hline NSE 75\% + CO 25\% & 3.50 & 25 & $12.00 \mathrm{a}$ & $38.68 \mathrm{~b}$ & $72.00 \mathrm{~b}$ & $89.00 \mathrm{~b}$ \\
\hline NSE 75\% + CO 25\% & 5.00 & 25 & $17.32 \mathrm{a}$ & $61.32 \mathrm{c}$ & $70.72 \mathrm{~b}$ & $82.00 \mathrm{~b}$ \\
\hline NSE 100\% & 5.00 & 25 & $17.32 \mathrm{a}$ & $50.68 \mathrm{bc}$ & $68.00 \mathrm{~b}$ & $78.68 \mathrm{~b}$ \\
\hline Control & - & 25 & $2.68 \mathrm{a}$ & $6.68 \mathrm{a}$ & $6.68 \mathrm{a}$ & $13.32 \mathrm{a}$ \\
\hline
\end{tabular}

Percentage mortality followed by different letters in the same column are significantly different at 5\% DMRT confidence level 
[3] D.A. Sunarto, Nurindah, Sujak, Pengaruh ekstrak biji mimba terhadap konservasi musuh alami dan populasi Helicoverpa armigera Hubner. pada tanaman kapas. J. Penel. Tan. Ind. 10 (2004) 8995.

mL/L was considered quite effective in causing the mortality of $H$. armigera and $S$. litura caterpillars. Essential oils such as clove oil and citronella oil are known as an insect repellent, but they also act as contact pesticides and fumigants against certain insects [11,12]: Willis [13] also reported that neem insecticide + essential oils (citronella) mixture is found work effectively in controlling main cocoa pests Helopeltis sp and Conopomorpha cramerella with efficacy values $>60 \%$ and increase $24.4 \%$ cocoa production. Clove oil can also be used to control pests on clove and cabbage $[14,15]$.

Generally, plants that have potential as botanical insecticide have a bitter taste (containing alkaloid and terpene) with a strong and spicy scent, so it disliked by pests Uhan [16]. Adding citronella oil to the neem seed extract formula can reduce the pungent odor caused by the neem seed solution odor. The more compositions of citronella oil added to the formula causes the spicy and robust scent of neem solution to decrease, and the aroma of citronella oil become more dominant. The addition of $25 \%$ citronella oil to NSE considered sufficient enough to reduce the pungent odor compared to the previous invention formula NSE $100 \%$ (comparison). The inclusion of citronella oil did not effect the efficiency of NSE in controlling $H$. armigera and $S$. litura compared to using pure NSE.

\section{CONCLUSION}

Mixture of $75 \%$ NSE + CO $25 \%$ at a concentration of $1.25 \mathrm{~mL} / \mathrm{L}$ effectively causes mortality for both caterpillars (Helicoverpa armigera and Spodoptera litura), and not significantly different when compared with treatments with higher concentrations $(2.5 \mathrm{~mL} / \mathrm{L}, 3.5$ $\mathrm{mL} / \mathrm{L}, 5 \mathrm{~mL} / \mathrm{L}$ ) and $100 \% \mathrm{NSE}$.

\section{ACKNOWLEDGMENT}

The author would like to thank the Agricultural Research and Development Agency for funding support for this research through the 2015 State Budget.

\section{REFERENCES}

[1] Subiyakto, D.A. Sunarto. Paten proses ekstraksi dan formulasi biji mimba (Azadirachta indica) sebagai pestisida. No \& tanggal pendaftaran P00200600708, 6 Desember, 2006.

[2] Subiyakto, Pestisida nabati ekstrak biji mimba untuk pengendalian serangga hama pada tanaman kapas. peningkatan produktivitas dan pendapatan petani kapas, J. Litbang. Pertan. (2013) 183-190

[4] D.A. Sunarto, Nurindah. Peran insektisida botani ekstrak biji mimba untuk konservasi musuh alami dalam pengelolaan serangga hama kapas. JEI. 6 (2009) 42-52.

[5] Nurindah, D.A. Sunarto, Sujak, Efektivitas dan kompatibilitas ekstrak biji mimba untuk pengendalian kompleks penggerek buah kapas. Bul. Littro. 23 (1) (2012) 48-60. ISSN 0215-0824

[6] Bottenberg, Singh. Effect of neem leaf extract applied using the broom method on cowpea pests and yield. Int. J. Pest Manage. 42 (3) (1996) 207209

[7] T.Y. Su, M.S. Mulla. Ovicidal activity of neem products (azadirachtin) against Culex tarsalis and Culex quinquefasciatus (Diptera; Culicidae), J. Am. Mosq. Control Assoc. (AMCA). 14 (2) (1998) 204-209.

[8] P. Pats, M.B. Isman, Effect of neem on adult longevity. oviposition and larval development of the cabbage fly. Delia radicum (L.) (Diptera; Anthomyidae). J. Appl. Entomol. 122 (1998) 125127

[9] Subiyakto, D.A. Sunarto, Sujak. Formula insektisida botani ekstrak biji mimba dengan penambahan minyak cengkih atau minyak serai wangi, Usulan paten, Balittas. 2019.

[10] W. Setawati, R. Murtiningsih. N. Gunani, T. Rubiati, Tumbuhan bahan pestisida botani. Balitsa. Lembang. Bandung, 2008, 203p.

[11] M.B. Isman, Plant essential oils for pest and disease management. Crop Protection, 19 (2000) 603-608.

[12] Wiratno, D. Taniwiryono, B.S. Sembiring, I.M. Trisawa, I.M.C.M. Rietjens, A.J. Murk, Laboratory and field studies on the effectiveness of botanical extracts and a newly formulated botanical pesticide formulation against pest of black pepper (Piper ningrum), 2008, 121p

[13] M. Willis, R. Balfas, M. Darwis, Ahyar, A. Suhenda. Evaluasi formulasi pestisida nabati berbahan aktif eugenol. sitronelal. dan azadirachtin untuk pengendalian hama utama kakao di Jawa Barat, Prosiding Kongres VIII dan Seminar Nasional Perhimpunan Entomologi Indonesia, 2012, pp. 672-683 ISBM: 978-97995399-9-1. 
[14] G. Indriati, Khaerati, F. Soesanty, Pengendalian terpadu serangga serangga penggerek cengkeh. Agroinovasi Agroscince Balitbangtan (2011) 3394.

[15] E.H. Krestini, S.U. Tinny, Potensi bahan nabati minyak nilam (Pogostemon cablin Benth) dan minyak cengkeh (Syzygium aromaticum) untuk pengendalian Plutella xylostella, Prosiding Kongres VIII dan Seminar Nasional Perhimpunan Entomologi Indonesia, 2012, pp. 388-394, ISBM: 978-979-95399-9-1

[16] T.S. Uhan, Daya bunuh beberapa jenis insektisida nabati terhadap ulat crop kubis (Crocidolomia pavonana), Prosiding Kongres VIII dan Seminar Nasional Perhimpunan Entomologi Indonesia, 2012, pp. 570-574, ISBM: 978-979-95399-9-1. 